\title{
Ground-motion prediction equation and site effect characterization for the central area of the Main Syncline, Upper Silesia Coal Basin, Poland
}

https://doi.org/10.1515/geo-2018-0037

Received Apr 20, 2018; accepted Jul 27, 2018

\begin{abstract}
The aim of the study was to find the best model of ground-motion prediction equation (GMPE) forecasting peak ground acceleration (PGA) caused by induced seismicity. The maximum values of PGA on the surface are a major seismic threat for the infrastructure, especially in the highly urbanized areas, such is the Upper Silesian Metropolitan Area.

The forecasting equations were estimated based on the values of PGA, epicenter distances and mining tremor energy registered by 14 surface seismometer stations located in the central area of the Main Syncline of the Upper Silesia Coal Basin. Data were collected within the period from January 2010 to December 2016, and the total number of seismic events used in the calculations was 15 541. The final model predicted the PGA values and amplification coefficients representing the characteristics of the site effects under seismometer stations.
\end{abstract}

Keywords: GMPE, site effects, amplification, Upper Silesia Coal Basin

\section{Introduction}

Underground mining of coal, in aseismic areas like the Upper Silesia Coal Basin (USCB) (Figure 1), leads to a disturbance of the rock mass equilibrium. Furthermore, it triggers or induces the accumulated elastic energy release as an earthquake that may result in perceptible shaking on the surface which can even damage the infrastructure. For hazard assessment purpose, it is necessary to predict scale of the ground motion based on the Ground-Motion Predic-

\footnotetext{
*Corresponding Author: Maciej Jan Mendecki: University of Silesia in Katowice, Bedzinska 60 Str., 41-200 Sosnowiec, Poland; Email: maciej.mendecki@us.edu.pl

Angelika Duda, Adam Idziak: University of Silesia in Katowice, Bedzinska 60 Str., 41-200 Sosnowiec, Poland
}

tion Equation, GMPE [1-4]. The GMPE, in addition to the parameter representing the source (energy) and path (distance), takes into account also the influence of the surface layer at the measurement site (amplification) [1, 2]. The highest attenuation takes place in a medium with inelastic properties, i.e. loose rocks [5-8]. However, for specific geological conditions of near surface layers, the amplitude amplification may occur for the corresponding resonance frequency of loose layers which is related to the velocity of seismic waves and the thickness of these layers [9].

Therefore, the main aim of the research was to find the best model of GMPE relation in the mining area of "Ziemowit" Coal Mine, located in the Upper Silesian Coal Basin in the central area of the Main Syncline (Figure 1) representing one of the most active mining areas [10]. A model of a forecasting equation was proposed which provides for local effects (amplification coefficient) at the location of seismometer stations. In addition, the parameter $h$, being the estimated depth of exploitation, was also taken into account in the calculation of the model $[3,5]$.

\section{Site characterization}

The "Ziemowit" Coal Mine is located in Bierun and Lędziny commune, and it belongs to the Polish Mining Group. The mine includes two mining areas: "Lędziny I" and "Imielin I" and their mining areas cover the entire city of Lędziny and partially: Imielin, Chełm Śląski, Bieruń, Tychy, Katowice and Mysłowice. The "Lędziny I" area is located in the central part of the Main Syncline in USCB where the hanging wall block of "Książęcy" normal fault is present. The layers are inclined in the South-East direction at an angle of $2^{\circ}-8^{\circ}$. Here, the coal seams are cut by a large number of faults that divide them into technical blocks [12]. Moreover, the major tectonic disturbances in this area are represented by: the Lędziński fault zone, the Imieliński-Wanda fault zone, the fault zone at the contact of Lędziński and Smardzowicki faults. The minor tectonic zones are represented by Chełmski fault, Eastern fault, Western fault, Pi- 


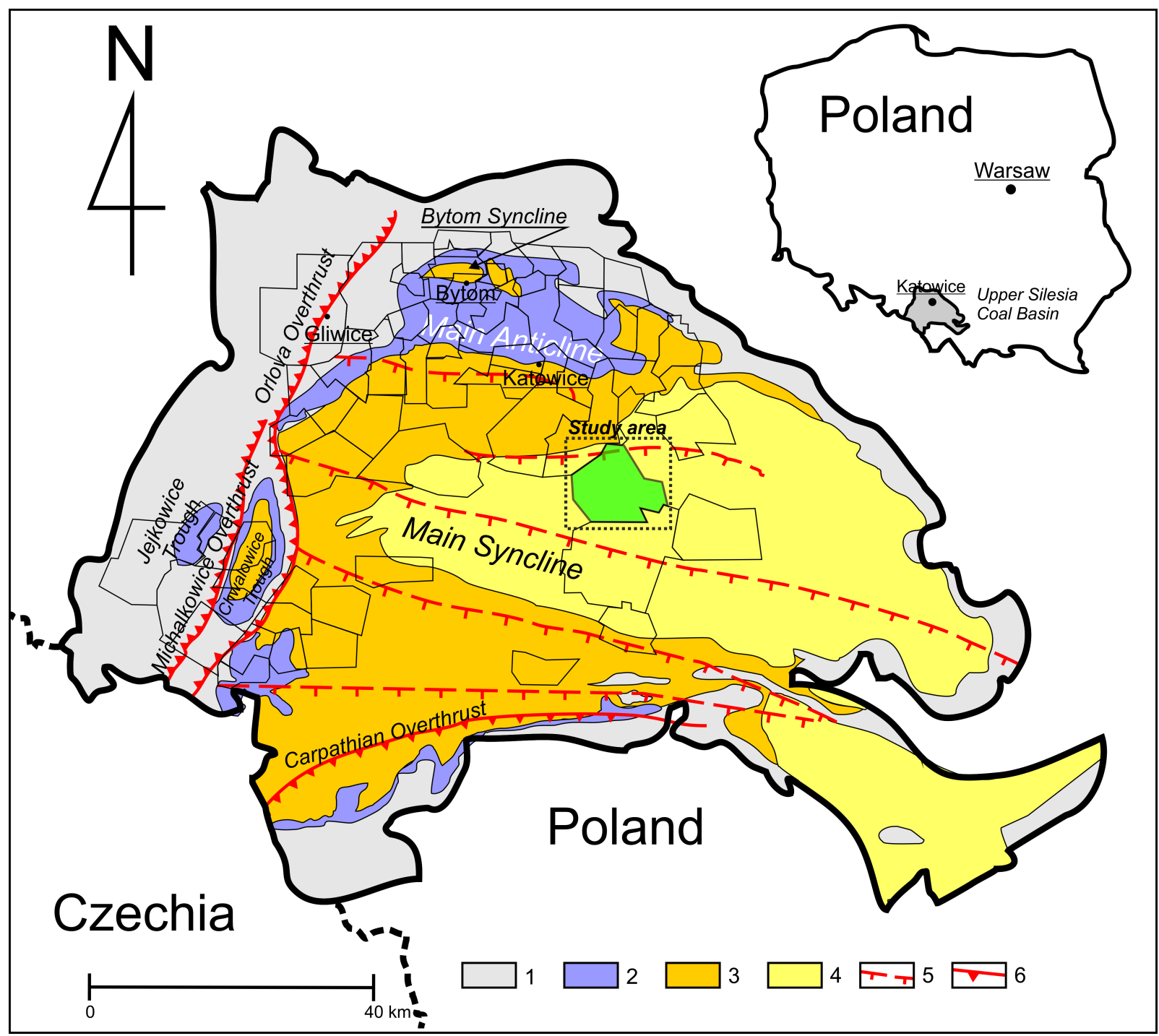

Figure 1: Lithostratigraphy and tectonics of the USCB: 1 - Paralic Series (upper Mississippian-lower Pennsylvanian), 2 - Upper Silesian Sandstone Series (lower Pennsylvanian), 3 - Mudstone Series (lower-middle Pennsylvanian), 4 - Krakow Sandstone Series (middle Pennsylvanian), 5 - important faults, 6 - overthrusts (Modified after Kędzior [11])

astowski fault and Ławecki fault (Figure 2). The "Imielin I" mining area is located on the border of the central and eastern part of the Main Syncline (the hanging wall block). Layers extend in the directions from S-N to NWW-SEE. The dip varies from $3^{\circ}-10^{\circ}$ and its azimuth changes from the north to the south Main Syncline. In the northern part, it is rather S, E and SE, but in the southern part it is SW [12]. The coal seams in this mining area are cut by many faults with throw reaching values of $160 \mathrm{~m}$. The largest dislocations have the NW-SE course and NS directions creating the Imieliński fault zone [12].

The overburden consists of the formations of the Quaternary and Tertiary (Table 1) [12]. Quaternary deposits are present in entire study area and cover Tertiary and Trias- sic layers which form the irregular arranged blocks. Below those rock, the Carboniferous creates a rigid basement. However, in some cases the Tertiary or Triassic formations are the rigid basement (Table 1).

The seismic stations located (Figure 2) in the northern part of the study area (Dziećkowice, SUW, Imielin, W-II) are installed in similar geological conditions, represented by approximately $30 \mathrm{~m}$ thick formation of the Quaternary sandy deposit (Table 2). Below the Quaternary complex, there are Tertiary sediments composed mainly of clays and silts, their thickness reaches $90 \mathrm{~m}$ and they cover Triassic marls formation. The central part of study area, where Rubinowa, Ziemowit, Goławice, Pompownia stations are located, is characterized by ca. $15 \mathrm{~m}$ sandy Quaternary 
Table 1: Outline of the geological structure in the area of Ziemowit Coal Mine [12]

\begin{tabular}{|c|c|c|c|}
\hline Age & Type of rocks & Thickness & Range \\
\hline $\begin{array}{l}\text { Quaternary } \\
\text { (fluvioglacial } \\
\text { deposits of the } \\
\text { Lower Pleistocene } \\
\text { and Holocene:) }\end{array}$ & $\begin{array}{l}\text { gray and yellow medium- and } \\
\text { fine-grained sands, and gray moraine } \\
\text { clays with gravel and silt inserts }\end{array}$ & $\begin{array}{l}\text { the thickness varies from } 0 \\
\text { (Bierun area) up to } 5 \mathrm{~m} \text { in the } \\
\text { eastern and north-eastern part } \\
\text { of Ziemowit mining area; the } \\
\text { largest thickness occurs in the } \\
\text { southern part of the area and is } \\
23.5 \mathrm{~m} \text { (near Chetm Wielki) }\end{array}$ & Quaternary covers the entire area. \\
\hline Tertiary & $\begin{array}{c}\text { these layers are represented by } \\
\text { gray-green clays, sandy clays and } \\
\text { marls }\end{array}$ & $\begin{array}{l}\text { the thickness varies from } 0 \text { to } \\
\text { the maximum value of } 328.4 \mathrm{~m}\end{array}$ & $\begin{array}{c}\text { appearing irregularly on uneven } \\
\text { surfaces of Carboniferous and Triassic } \\
\text { deposits }\end{array}$ \\
\hline $\begin{array}{c}\text { Triassic } \\
\text { (Buntsandstein, Ret } \\
\text { and Muschelkalk) }\end{array}$ & $\begin{array}{l}\text { sandy and silty sediments with a } \\
\text { thickness of } 12-23 \text { m below which } \\
\text { there are Muschelkalk deposits } \\
\text { (marls) and Ret dolomites as well as } \\
\text { gray (pellet) limestones, crinoid } \\
\text { limestones with marl inserts. }\end{array}$ & $\begin{array}{c}\text { the thickness ranges from } 0 \mathrm{~m} \text { - } \\
6 \mathrm{~m} \text { up to } 54.4 \mathrm{~m} \text { and reaches a } \\
\text { maximum of } 122.1 \mathrm{~m}\end{array}$ & $\begin{array}{l}\text { it lies irregularly on the } \\
\text { Carboniferous, forming blocks, it is } \\
\text { present mainly in the eastern and } \\
\text { north-western part of the mining area }\end{array}$ \\
\hline Carboniferous & $\begin{array}{l}\text { Libiąż layers (Westphal D), Laziska } \\
\text { layers (Westphal C), Orzesze layers } \\
\text { (Westphal B) }\end{array}$ & - & $\begin{array}{l}\text { A solid rock basement covering the } \\
\text { entire area }\end{array}$ \\
\hline
\end{tabular}

deposit covering very thick formation of Tertiary formations (thickness reaches $170 \mathrm{~m}$ ) (Table 2). In the vicinity of Fawent and Chełm stations, the Triassic marls are very shallow - ca. $25 \mathrm{~m}$ below the surface(Table 2), and they are covered by a 20-meters layer of sands (Quaternary) and a thin 5-meter layer of silts (Teriary) (Table 2). The southern part of the study area (Czerniny and Kopciowice stations) is located in the area where the Quaternary deposit is about $15 \mathrm{~m}$ thick and covers a 35 -meters formation of Tertiary sediments and Triassic marls (Table 2). Specific geology can be found below the Zapora station, there are 9meter thick Quaternary sediments (sands and clays) covering a 9-meter thick Tertiary silt and this last layer is situated on Triassic dolomites (Table 2) [12].

\section{Data and methods}

\subsection{Seismic data}

In the period from January 2010 to December 2016, a total of 15541 seismic events were recorded by 14 seismometer stations (triangles in Figure 2). The coordinates of the stations in the Sucha Gora geodetic system and the number of data taken for analysis are presented in Table 2, and their location is shown in Figure 2. The measurements were carried out using the AMAX-GSI equipment, that is a multichannel network of seismometers recording accelerations of seismic waves on the surface. Each station is composed of a three-component piezoelectric accelerometer integrated with a preamplifier, amplifier and a digital recorder connected to a PC with the SEJSGRAM and AMAX software installed and matched with a 16-bit AC converter card. The accelerometer is characterized by frequency range of 1$100 \mathrm{~Hz}$ and dynamics of 70-80 dB with the maximum value of recorded acceleration equal to $3 \mathrm{~m} / \mathrm{s}^{2}$. The positioning of the sensors ensures that they have good contact with the ground. Their installation place depends on space availability and they were fixed either to the load-bearing wall on the ground floor of the building or to the foundation wall in in basement. This network allowed to collect the PGA data from the studied period 2010-2016.

The energies and locations of the recorded event were calculated using the Seismological Observation System (SOS) developed by the Central Mining Institute in Katowice. The SOS consists of the network of 37 underground geophones and 6 surface seismometers [12]. Determination of energy and localization of mining tremors were carried out using the MultiLok program provided by the Central Mining Institute as well.

Both these systems (AMAX and SOS) allowed to complete the seismic catalog that was used in the GMPE model calculation. The catalog contained information on: time of event occurrence, location of the event (Sucha Góra coordinate system), event energy, and value of PGA recorded by the surface stations. 


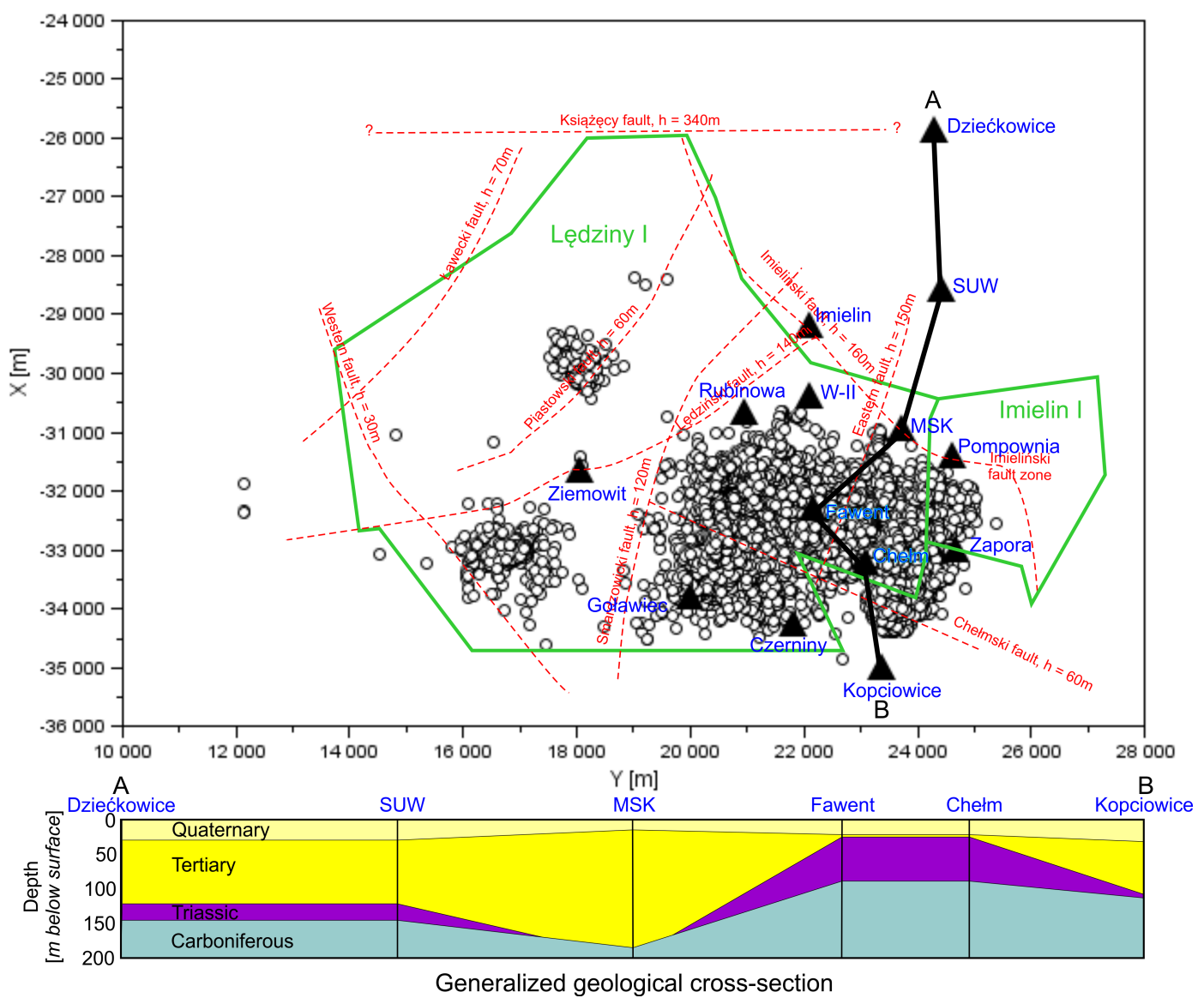

Figure 2: Map of seismometer station locations on July 25, 2016 (black triangles), epicenters of mining tremors (dots) recorded during the period from 2010 - 2016, mining area (green lines) and main faults (red dashed lines) - all data are in the Sucha Góra geodetic system. Below the map: generalized geological cross-section $A B$ with main geological formations.

\subsection{GMPE model and evaluation}

The GMPE model, chosen for calculation, was proposed by Lasocki [3] and it represents a regression model considering energy, mechanisms of amplitude decrease over distance (the geometric spreading), and site effects (relative amplification coefficients). The regression model can be expressed as [1, 3]:

$$
\log P G A_{x y}=\alpha+\beta \log E-\gamma \log \sqrt{R^{2}+h^{2}}+\sum_{i=1}^{14} a_{i} \delta_{i j}
$$

where $\alpha, \beta$ and $\gamma$ are regression parameters corresponding to energy $E$ and geometric spreading at the wave path (distance), respectively, the distance between source and site is represented by $\sqrt{R^{2}+h^{2}}$ where $R$ is the epicenter distance and $h$ is the depth parameter (iteratively searched). The $h$-value is introduced to the equation due to the uncertainty of Z-component of earthquakes location and to deal with this the average depth must be found. The last segment of the GMPE model considers site effects and $a_{i}$ denotes the logarithmized amplification factor and $\delta_{i j}$ is the Kronecker's delta indicating whether an event was recorded on site or not. Moreover, this model was chosen as it produced better statistical results than models without the $h$ parameter and the site effect segment.

The regression model was obtained using the Normal Equation System to find a solution of multiple regression. Statistical assessment of the model was also carried out and the fitting quality of the model was confirmed by: determination coefficient $R^{2}$, dispersion plot, standard error of estimate SEE and analysis of residuals [2]. Relative amplification coefficient is logarithmized, thus to obtain a full value, the $a_{i}$ is raised to power. Moreover, this value is relative and is calculated as a difference between the consid- 
Table 2: The coordinates of seismic station in the Sucha Góra system together with the number of registrations taken for the purpose of the analysis and geological settings below stations [12]

\begin{tabular}{|c|c|c|c|c|c|c|c|c|}
\hline \multirow[t]{2}{*}{ No. } & \multirow[t]{2}{*}{$\begin{array}{l}\text { Seismometer } \\
\text { station }\end{array}$} & \multicolumn{3}{|c|}{$\begin{array}{l}\text { Coordinates in the Sucha } \\
\text { Góra geodetic system }\end{array}$} & \multirow{2}{*}{$\begin{array}{c}\text { Number of data } \\
\text { recorded at each } \\
\text { station }\end{array}$} & \multicolumn{3}{|c|}{$\begin{array}{c}\text { Thickness [m] } \\
\text { (main type of rock) }\end{array}$} \\
\hline & & $\mathrm{X}$ & $\mathbf{Y}$ & $\begin{array}{l}\text { Elevation } \\
\text { [m a.s.l.] }\end{array}$ & & $\mathbf{Q}$ & $\mathrm{Tr}$ & $T$ \\
\hline 1 & Fawent & -32360 & 22170 & 245 & 2943 & $\begin{array}{c}22.0 \\
\left(\text { sands }^{1}\right)\end{array}$ & 4.0 (silts) & $\begin{array}{c}65.0 \\
\text { (limest.) }\end{array}$ \\
\hline 2 & Gotawiec & -33878 & 19987 & 240 & 1614 & $\begin{array}{c}13.4 \\
\left(\text { sands }^{2}\right)\end{array}$ & $\begin{array}{l}142.6 \\
\text { (silts) }\end{array}$ & $\begin{array}{c}12.7 \\
\text { (marls) }\end{array}$ \\
\hline 3 & Chetm & -33272 & 23082 & 244 & 4497 & $\begin{array}{c}22.0 \\
\left(\text { sands }^{1}\right)\end{array}$ & 4.0 (silts) & $\begin{array}{c}55.5 \\
\text { (limest.) }\end{array}$ \\
\hline 4 & Imielin & -29253 & 22119 & 263 & 397 & $\begin{array}{l}30.0 \\
\left(\mathrm{till} l^{+}\right)\end{array}$ & $\begin{array}{c}210.0 \\
\text { (siltst. }^{3} \text { ) }\end{array}$ & $\begin{array}{c}20.0 \\
\text { (congl.) }\end{array}$ \\
\hline 5 & Szyb W-II & -30472 & 22091 & 253 & 365 & $\begin{array}{c}28.5 \\
\left(\text { sands }^{+}\right)\end{array}$ & $\begin{array}{c}232.5 \\
\text { (siltst. }^{3} \text { ) }\end{array}$ & - \\
\hline 6 & Rubinowa & -30725 & 20972 & 261 & 757 & 15.1 (till) & - & - \\
\hline 7 & Pompownia & -31485 & 24626 & 235 & 1397 & $\begin{array}{c}12.0 \\
\left(\text { sands }^{+}\right)\end{array}$ & $\begin{array}{c}171.9 \\
\left(\text { marls }^{4}\right)\end{array}$ & - \\
\hline 8 & Zapora & -33077 & 24668 & 236 & 2219 & $\begin{array}{c}9.0 \\
\left(\text { sands }^{+}\right)\end{array}$ & 9.0 (silts) & $\begin{array}{c}11.0 \\
\text { (limest.) }\end{array}$ \\
\hline 9 & Ziemowit & -31724 & 18059 & 257 & 221 & $\begin{array}{r}15.0 \\
\left(\text { till }^{+}\right)\end{array}$ & - & - \\
\hline 10 & MSK & -31020 & 23737 & 244,5 & 506 & $\begin{array}{c}12.0 \\
\left(\text { sands }^{+}\right)\end{array}$ & $\begin{array}{c}171.9 \\
\left.(\operatorname{marls})^{4}\right)\end{array}$ & - \\
\hline 11 & Kopciowice & -35057 & 23369 & 245 & 237 & $\begin{array}{c}39.0 \\
\text { (sands) }\end{array}$ & 19.0 (till) & $\begin{array}{c}53.5 \\
\text { (limest.) }\end{array}$ \\
\hline 12 & Czerniny & -34324 & 21813 & 239 & 230 & $\begin{array}{c}16.0 \\
\text { (sands) }\end{array}$ & $\begin{array}{l}34.5 \\
\text { (silts) }\end{array}$ & $\begin{array}{c}48.0 \\
\text { (limest.) }\end{array}$ \\
\hline 13 & SUW & -28652 & 24415 & 260 & 114 & $\begin{array}{c}31.0 \\
\left(\text { sands }^{+}\right)\end{array}$ & $\begin{array}{l}89.7 \\
\text { (silts) }\end{array}$ & $\begin{array}{c}19.7 \\
\text { (dolom.) }\end{array}$ \\
\hline 14 & Dziećkowice & -25961 & 24304 & 260 & 44 & $\begin{array}{c}30.5 \\
\left(\text { sands }^{+}\right)\end{array}$ & $\begin{array}{l}89.7 \\
\text { (silts) }\end{array}$ & $\begin{array}{c}19.8 \\
\text { (dolom.) }\end{array}$ \\
\hline
\end{tabular}

Abbreviations: 1 - fine-grained, 2 - medium-grained, “+”- with additional tills or sands inserts, 3 - with clays and marls inserts, 4 - clays inserts, limest. - limestones, siltst. - siltstone, congl. - conglomerates, dolom. - dolomites.

ered value and the reference value as follow [2]:

$$
A_{G M P E}=10^{a_{i}-a_{\text {ref }}}
$$

In this case, the lowest $a_{i}$ is assumed as the reference value [2].

\section{Results and discussion}

The best model of GMPE was searched iteratively with respect to the $h$ parameter representing depth. The $h$-value was changed from $200 \mathrm{~m}$ to $1200 \mathrm{~m}$ below surface with the step of 50m (Figure 3). The assessment of the best model was based on the values of $\mathrm{R}^{2}$ and SEE (Figure 3 ) and it indicated that the satisfactory results were obtained for $h=$ $900 \mathrm{~m}$ because $\mathrm{SEE}=0.232$, where it actually assumes the lowest value and it corresponds to the highest value of $\mathrm{R}^{2}$ $=0.74$ (Table 3). Moreover, this depth below surface corresponds to the average depth of exploitations in the mine.

The calculated regression model parameters and descriptive statistics were compared in Table 3. A similar study was carried out for the "Ziemowit" mine in 2012 [2]. Comparing the regression parameter values with those calculated in the paper by Golik and Mendecki [2] with those 


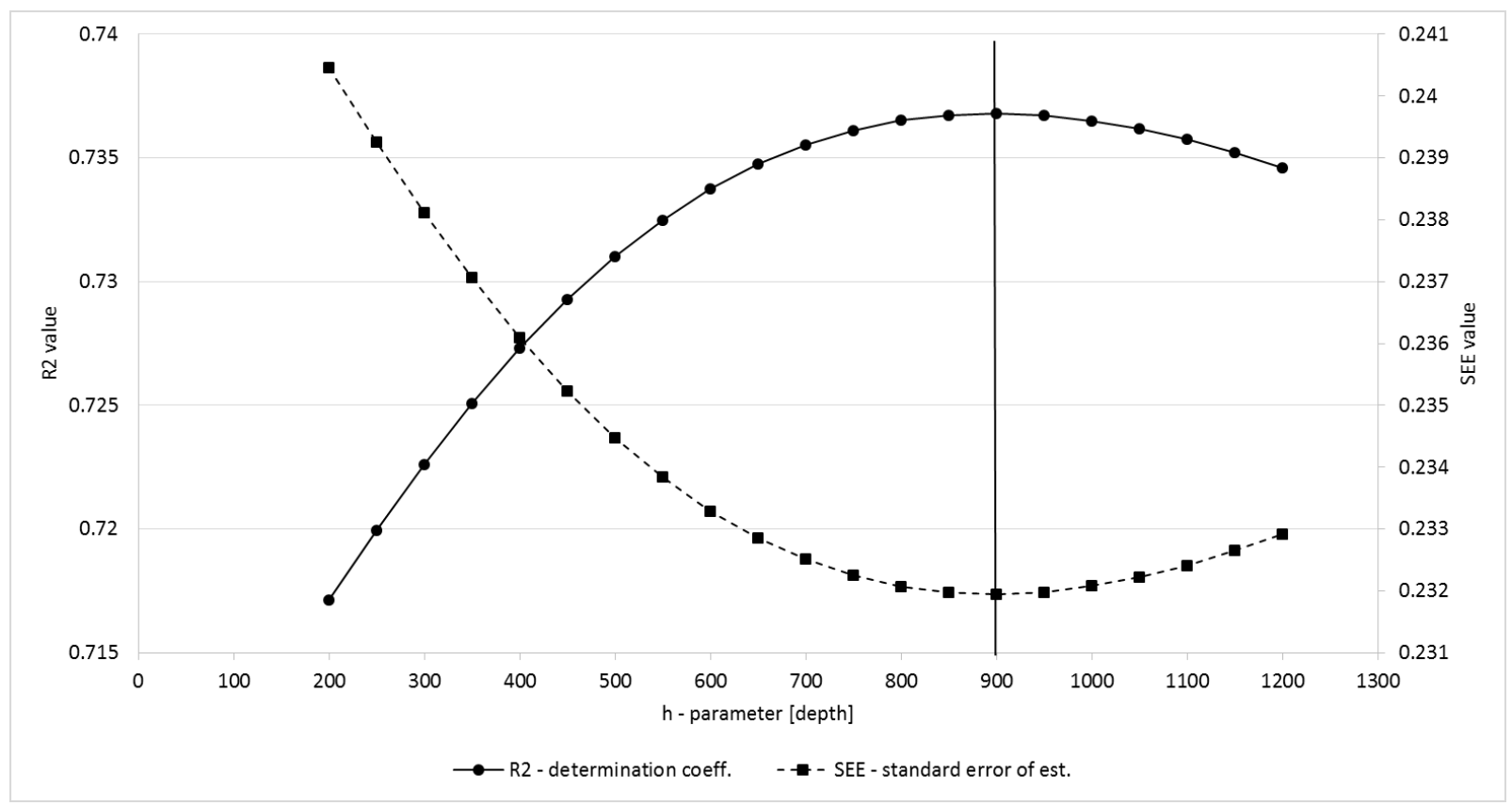

Figure 3: Changes of $\mathrm{R}^{2}$ and SEE values with increasing $h$-parameter. Best solution for $h=900 \mathrm{~m}$.

Table 3: Results of multiple regression with statistical assessment and calculated $A_{G M P E}$

\begin{tabular}{|c|c|c|c|c|c|c|c|}
\hline Site & $\begin{array}{l}\text { Logarithmized } \\
\text { amplification factor } a_{i}\end{array}$ & $\begin{array}{l}\text { Relative amplification } \\
\qquad A_{G M P E}\end{array}$ & $\alpha$ & $\boldsymbol{\beta}$ & $\gamma$ & $\mathbf{R}^{2}$ & SEE \\
\hline Fawent & -0.427 & 1.59 & 4,522 & 0.483 & -1.674 & 0.74 & 0.232 \\
\hline Gotawiec & -0.335 & 1.96 & & & & & \\
\hline Chetm & -0.256 & 2.35 & & & & & \\
\hline Imielin & -0.263 & 2.31 & & & & & \\
\hline Szyb W-II & -0.395 & 1.71 & & & & & \\
\hline Rubinowa & -0.415 & 1.63 & & & & & \\
\hline Pompownia & -0.615 & 1.03 & & & & & \\
\hline Zapora & -0.059 & 3.70 & & & & & \\
\hline Ziemowit & -0.375 & 1.79 & & & & & \\
\hline MSK & -0.226 & 2.52 & & & & & \\
\hline Kopciowice & -0.362 & 1.84 & & & & & \\
\hline Czerniny (reference) & -0.627 & 1.00 & & & & & \\
\hline SUW & -0.286 & 2.19 & & & & & \\
\hline Dziećkowice & -0.136 & 3.10 & & & & & \\
\hline
\end{tabular}

obtained here, only $\gamma$ remains the same. It can be also treated as another qualitative confirmation of correctness of the model as it indicates that the coefficient of geometric scattering (associated with geology) has been preserved. The $\beta$ value in this study is higher than the previous one [2]. This parameter is related to the $b$-value of Gutenberg-Richter [13], thus the increase of the data set can change or refine the $b$-value. This can explain changes in $\beta$ parameter. The data set presented here is larger than the one used in [2]. The same reason might apply to the differences in the relative amplification coefficients. In this study, the number of seismic data and number of sites increase as well.

Next, the map of spatial distribution of the relative amplification coefficients $A_{G M P E}$ was prepared (Figure 4A) using the block kriging as the gridding method with a linear drift function $[14,15]$. The map was prepared in the Surfer 10 software. The semi-variogram model applied to the data was a power function. The grid was the size of 100 rows and 73 columns. The descriptive statistics for the analyzed 


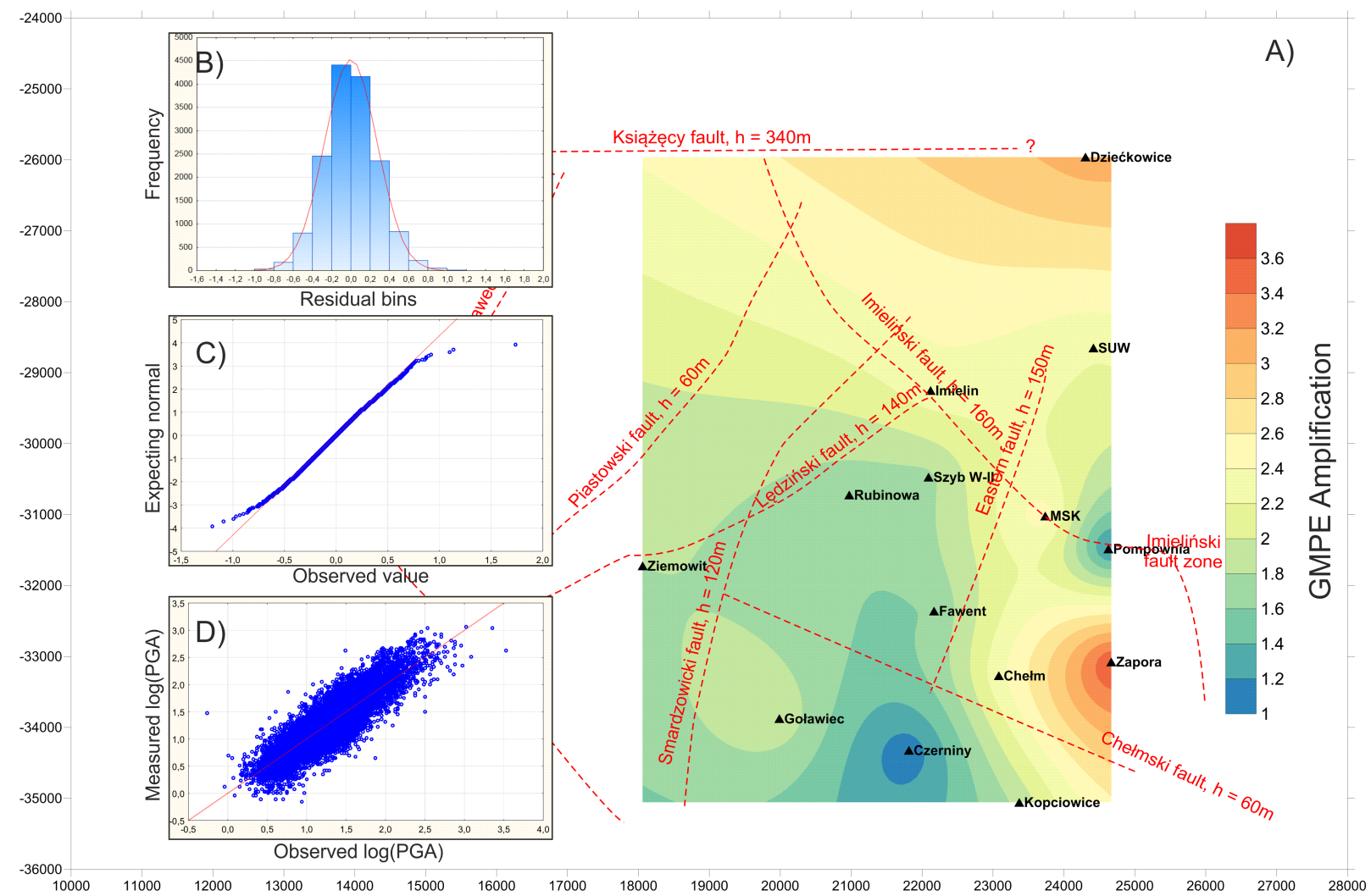

Figure 4: Spatial distribution of $A_{G M P E}(\mathrm{~A})$ with the statistical assessment plots: histogram of residuals (B), normality plot (C) and dispersion plot (D)

data set of 14 relative amplification coefficients are characterized by the mean value of 2.1, standard deviation of 0.4 , maximum value of 3.6 and minimum value of 1.0 .

The calculated GMPE amplification values range from 1 to 3.7. The strongest site effects $\left(A_{G M P E}>2\right)$ can be reported for the station areas in: Dzieckowice, Imielin, Chełm, MSK SUW and Zapora. At the last station (Zapora), $A_{G M P E}$ was the highest and reached 3.7 (Table 3). The GMPE model was also assessed by means of further statistical techniques which confirmed correctness and good fit of the model. The analysis of residuals indicated that residuals are focused around zero (Figure 4B) and the residual histogram has the Gaussian-shape distribution [2, 5]. The reliability of the model is also confirmed by the normality plot (Figure 4C) which is almost a straight line with minor discrepancies at the ends. In Figure 4D, the dispersion plot was placed. It represents the relation of the predicted PGA versus observed PGA. Its cigar-shape is also the confirmation that the model reproduces estimated (predicted) data well. According to Lasocki [3], the visual inspection of residuals characteristics (Figure 5) also allows to assume that the residuals do not depend on the station location (Figure 5A), because the mean residuals have very small values (near zero) and 95\% confidence intervals associated with the station locations indicated the value zero falls well within the respective confidence intervals. Moreover, there is no distinct dependence of residuals on the epicentral distance (Figure 5B).

The statistical analysis of the proposed model (Figure 4) and inspection of the residuals (Figure 5) convince that the calculations made are appropriate and the GMPE relation can be used for seismic hazard study. Figure 6 shows the last comparisons between the observed amplitudes, predicted values that are the medians $[1,3]$ as well as $95 \%$ confidence intervals for prediction that were calculated according to the formula presented in $[1,3]$. The values were sorted in a descending order of estimates and the amplitude values were unlogarithmized. Most of the observed amplitudes fall within the confidence intervals, and only $2.7 \%$ of cases exceed the upper limit ( 417 cases) as well as $2.2 \%$ of cases are below the lower limit (345 cases).

Thicknesses of the loose layers, in which the amplification may occurred, vary on the entire study area. Comparison of the calculated values of $A_{G M P E}$ with the thicknesses of Quaternary deposit or combination of Quaternary and Tertiary loose sediments (Table 4) indicated 
Table 4: Comparison of geology settings with the $A_{G M P E}$ values

\begin{tabular}{|c|c|c|c|c|c|}
\hline \multirow[t]{2}{*}{ No. } & \multirow[t]{2}{*}{ Seismometer station } & \multicolumn{3}{|c|}{ Thickness [m] (main type of rock) } & \multirow[t]{2}{*}{$\mathbf{A}_{\text {GMPE }}$} \\
\hline & & $\mathbf{Q}$ & $\operatorname{Tr}$ & $\mathbf{T}$ & \\
\hline 1 & Fawent & $22.0\left(\right.$ sands $\left.^{1}\right)$ & 4.0 (silts) & 65.0 (limest.) & 1.59 \\
\hline 2 & Goławiec & $13.4\left(\right.$ sands $\left.^{2}\right)$ & 142.6 (silts) & 12.7 (marls) & 1.96 \\
\hline 3 & Chetm & $22.0\left(\right.$ sands $\left.^{1}\right)$ & 4.0 (silts) & 55.5 (limest.) & 2.35 \\
\hline 4 & Imielin & $30.0\left(\right.$ till $\left.^{+}\right)$ & 210.0 (siltst. $\left.{ }^{3}\right)$ & 20.0 (congl.) & 2.31 \\
\hline 5 & Szyb W-II & $28.5\left(\right.$ sands $\left.^{+}\right)$ & 232.5 (siltst. $^{3}$ ) & - & 1.71 \\
\hline 6 & Rubinowa & 15.1 (till) & - & - & 1.63 \\
\hline 7 & Pompownia & $12.0\left(\right.$ sands $\left.^{+}\right)$ & $171.9\left(\right.$ marls $\left.^{4}\right)$ & - & 1.03 \\
\hline 8 & Zapora & $9.0\left(\right.$ sands $\left.^{+}\right)$ & 9.0 (silts) & 11.0 (limest.) & 3.70 \\
\hline 9 & Ziemowit & $15.0\left(\right.$ till $\left.^{+}\right)$ & - & - & 1.79 \\
\hline 10 & MSK & $12.0\left(\right.$ sands $\left.^{+}\right)$ & $171.9\left(\right.$ marls $\left.^{4}\right)$ & - & 2.52 \\
\hline 11 & Kopciowice & 39.0 (sands) & 19.0 (till) & 53.5 (limest.) & 1.84 \\
\hline 12 & Czerniny & 16.0 (sands) & 34.5 (silts) & 48.0 (limest.) & 1.00 \\
\hline 13 & suw & $31.0\left(\right.$ sands $\left.^{+}\right)$ & 89.7 (silts) & 19.7 (dolom.) & 2.19 \\
\hline 14 & Dziećkowice & $30.5\left(\right.$ sands $\left.^{+}\right)$ & 89.7 (silts) & 19.8 (dolom.) & 3.10 \\
\hline
\end{tabular}

1 - fine-grained, 2 - medium-grained, “+”- with additional tills or sands inserts, 3 - with clays and marls inserts, 4 - clays inserts, limest. limestones, siltst. - siltstone, congl. - conglomerates, dolom. - dolomites.

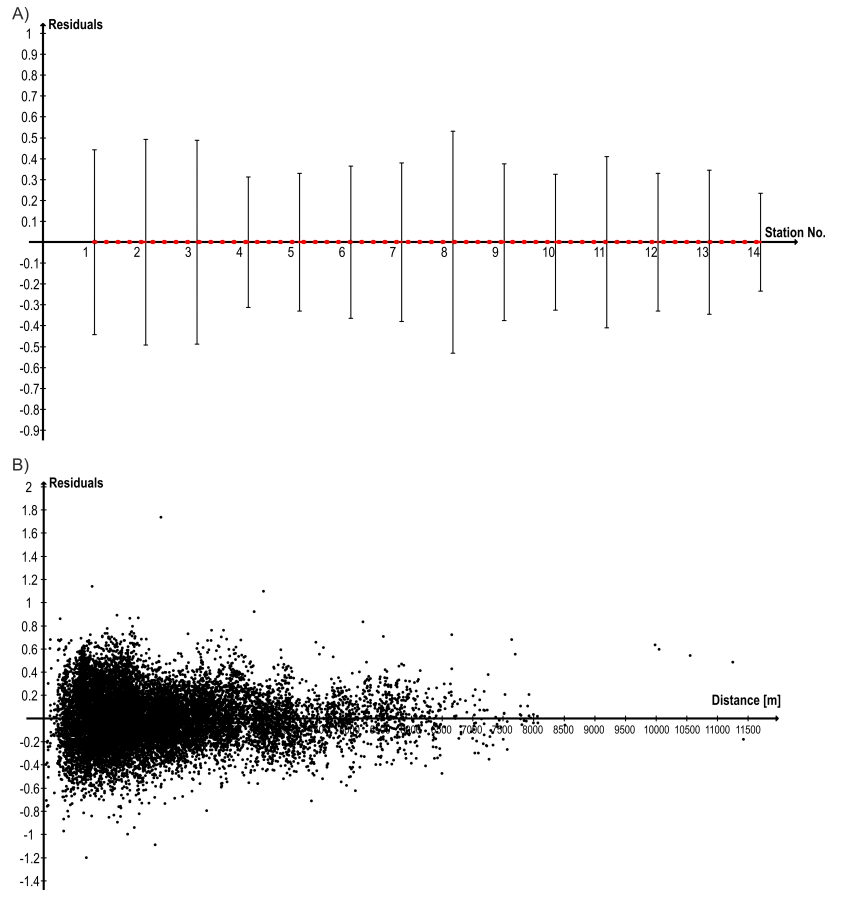

Figure 5: Residual characteristics: a) mean residuals (red dashed line) and $95 \%$ confidence intervals with respect to the station location; b) residuals vs. epicentral distance

that there is no visible correlation. The correlation coefficient for Quaternary thickness and $\mathrm{A}_{G M P E}$ reached value of 0.026. Here, the thickness varies in small range from 9 to $31 \mathrm{~m}$ and this layer is mainly composed of sand with tilt

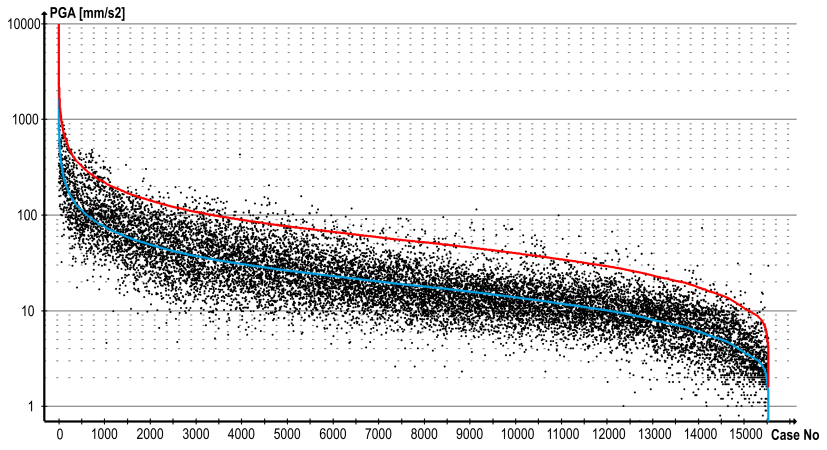

Figure 6: Observed amplitudes (black dots) and estimated median values (blue line), the red line represents the upper limits of $95 \%$ confidence intervals for the prediction

inserts, thus it can be assumed that there are similar geological conditions.

Due to the lack of correlation for Quaternary deposits we assumed cumulative thickness of all loose sediments (Quaternary and Tertiary) and the correlation coefficient was still low $(r=0.153)$, what also indicated that there is a lack of visible relation between amplification coefficient and thickness. Therefore, it seems that this relation might be more complex and considers other petrophysical parameters such as wave velocities, densities or water content that should be taken into account. However, this parameters remain still unknown and require next tests. More common approach is to compare resonance frequency of loose layer with thickness and some authors [16-18] reported that there is a clear power-law re- 
lation between these two parameters, but in this case the GMPE relation did not provide such data. The best solution will be to carry out HVSR measurements introduced by Nakamura [19].

Additional problem is the boundary between amplifying layer and rigid substratum. The geology is complex thus there is difficulty to find the appropriate thickness of the loose layer that can be excited by seismic waves. This aspect could also have an influence on the lack of correlation.

\section{Conclusion}

The statistical evaluation of the proposed GMPE model allows to state that this model can be used in the future PGA prediction in the central part of the Main Syncline of the USCB. The reliability of the model was confirmed by:

- analysis of residuals that allows to check the quality of models;

- coefficient of determination that informs what percentage of the original variability of the dependent variable was explained by the model;

- standard error of estimation;

- visual inspection of residual characteristics that showed that the mean residuals possess very small values (near zero) and 95\% confidence intervals associated with the station locations indicated the value of zero and the residuals did not depend on epicentral distances;

- and, finally, less than $5 \%$ of data exceeded the $95 \%$ confidence intervals.

Comparing the obtained relative amplification coefficients with the geological settings, it can be concluded that the highest amplification values and, thus, the seismic hazard occur in the outskirts of the Syncline (N, NE and SE), i.e. on the opposite sides of the basin. The lowest amplification values, therefor the lowest seismic hazard areas, are located in the central part of the studied area, in the zone of a block formed by faults: Lędziński, Imlieliski, Eastern and Chełmski which are in the main axis of the Syncline in the W-E direction.

Acknowledgement: The authors would like to thank the director and the employees of the Piast-Ziemowit Coal Mines for all support and consent to publish this work. The authors would like to highlight the significance of the reviewers' comments that improved this paper and would like to thank them for their revisions.

\section{References}

[1] Olszewska D., Attenuation relations of ground motion acceleration response spectra for the Polkowice Region. Publs. Inst. Geophys. Pol. Acad. Sci, 2006, 1000(395), 161-174.

[2] Golik A., Mendecki M., Ground-motion prediction equations for induced seismicity in the main anticline and main syncline, Upper Silesian Coal Basin, Poland. Acta Geophysica, 2012, 60(2), 410-425.

[3] Lasocki S., Site specific prediction equations for peak acceleration of ground motion due to earthquakes induced by underground mining in Legnica-Głogów Copper District in Poland. Acta Geophysica, 2013, 61(5), 1130-1155.

[4] Chodacki J., New Ground Motion Prediction Equation for Peak Ground Velocity and Duration of Ground Motion for Mining Tremors in Upper Silesia. Acta Geophysica, 2014, 64(6), 24492470.

[5] Lasocki S., Relacja tłumienia wartości szczytowej składowej poziomej przyspieszenia drgań gruntu w paśmie częstotliwości do $10 \mathrm{~Hz}$ dla rejonu miasta Polkowice. Publs. Inst. Geophys. Pol. Acad Sci., 2002, M-27 (352), 79 - 90 (in Polish).

[6] Campbell K.W., Strong-motion attenuation relations. In: Lee W.H.K., Kanamori H., Jennings P.C., Kisslinger C. (Eds.), International Handbook of Earthquake and Engineering Seismology, Part B, IASPEI, 2003, 1003-1012.

[7] Frej A., Zuberek W., Dyskusja nad amplifikacją drgań sejsmicznych w rejonie niecki bytomskiej. WUG: Bezpieczeństwo Pracy i Ochrona Środowiska w Górnictwie, 2007. 6, 35-37 (in Polish).

[8] Frej A., Zuberek W. M., Local effects in peak accelerations caused by mining tremors in Bytom Syncline Region (Upper Silesia). Acta Geodyn. Geomater, 2008, 5(2), 150.

[9] Bonnefoy-Claudet S., Cotton F., Bard P., The nature of noise wavefield and its applications for site effects studies: A literature review. Earth-Science Reviews, 2006, 79, 205-227.

[10] Stec K., Characteristics of seismic activity of the Upper Silesian Coal Basin in Poland. Geophysical Journal International, 2007, 168(2), 757-768.

[11] Kędzior S., Methane contents and coal-rank variability in the Upper Silesian Coal Basin, Poland. International Journal of Coal Geology, 2015, 139, 152-164.

[12] Documentation of Ziemowit Coal Mine in Lędziny

[13] Boore D.M., Atkinson G.M., Ground-motion prediction equations for the average horizontal component of PGA, PGV, and 5\%-damped PSA at spectral periods between $0.01 \mathrm{~s}$ and 10.0 s. Earthquake Spectra, 2008, 24(1), 99-138.

[14] Hudson G., Wackernagel H., Mapping temperature using kriging with external drift: theory and an example from Scotland. International journal of Climatology, 1994, 14(1), 77-91.

[15] Ciotoli G., Stigliano F., Marconi F., Moscatelli M., Mancini M., Cavinato G.P., Mapping the anthropic backfill of the historical center of Rome (Italy) by using intrinsic random functions of order k (IRF-K). In: Murgante B., Gervasi O., Iglesias A., Taniar D., Apduhan B.O. (Eds.) International Conference on Computational Science and Its Applications, Springer, Berlin, Heidelberg, 2011, 92-102.

[16] Delgado J., Lopez Casado C., Giner J., Estevez A., Cuenca A, Molina S., Microtremors as a Geophysical Exploration Tool: Applications and Limitations. Pure and Applied Geophysics, 2000, 
157, $1445-1462$.

[17] Dinesh B.V., Nair G.J. Prasad A.G.V., Nakkeeran P.V., Radhakrishna M.C., Relation between sedimentary layer thickness and fundamental frequency of the $\mathrm{H} / \mathrm{V}$ spectra for Bangalore city. Current Science, 2009, 97, 7, 1073-1077.

[18] Mendecki M.J., Bieta B., Mycka M., Determination of the resonance frequency-thickness relation based on the ambient seismic noise records from Upper Silesia Coal Basin. Contemporary Trends in Geoscience, 2014, 3(1), 41-51.
[19] Nakamura Y., A method for dynamic characteristics estimation of subsurface using microtremor on the ground surface. QR Railway Tech. Res. Inst., 1989, 30(1), 25-33. 